\title{
MODELOVANIE PROCESOV V POŠTOVÝCH SLUŽBÁCH
}

\author{
Lucia Madleňáková*
}

\section{Úvod}

Riadenie procesov v poštovom podniku je spojené s ich jednoznačným zadefinovaním. Často ide o riadenie vel'kého počtu vzájomné prepojených procesov, pričom významnú úlohu z hl'adiska dosahovania požadovanej efektívnosti systému zohráva aj ich usporiadanie a logická nadväznost' nielen medzi hlavnými procesmi, ale aj medzi pomocnými operáciami smerom k hlavným procesom. Modelovanie procesov, či už základných alebo podrobných subprocesov je pri zohl'adnení ich vlastnosti jedným z klúčových prvkov pre budúce uplatňovanie nástrojov riadenia kvality, diagnostiky či optimalizácie.

\section{Ciel' a metodika}

Ciel'om príspevku je demonštrovat' spôsob a možnosti modelovania poštových procesov. Berúc do úvahy fakt, že poštové služby sú poskytované vo funkčných technologických systémoch, ktorých konštrukcia z pohl'adu modelovania môže byt' zložitá, je vhodné $\mathrm{z}$ tohto pohl'adu pristúpit' $\mathrm{k}$ abstrakcii. Abstrakciu je bežným prvkom uplatňovaným v modelovaní a umožňuje zjednodušenie skúmaného problému. Následne uplatnením princípov dekompozície základného procesu poštovej služby na čiastkové procesy je možné modelovat' tento proces $\mathrm{v}$ zmysle zadaných požiadaviek.

\section{Teoretické vymedzenie skúmanej problematiky}

Modelovanie a riadenie procesov v poštových podnikoch je vo všeobecnosti obdobné ako v iných odvetviach. Podstatným rozdielom oproti výrobnej sfére je však definovanie technologických a netechnologických procesov. Vo výrobnej sfére technologické procesy tvoria skupinu základných (core) procesov bezprostredne súvisiacich s výrobou, pri ktorých dochádza $\mathrm{k}$ transformácií vstupov na výstupy s pridanou hodnotou. Netechnologické procesy sú v tejto oblasti chápané ako procesy podporné, nedochádza pri nich k tvorbe pridanej hodnoty. Môžeme tu zaradit' procesy súvisiace s dopravou, logistikou, manipuláciou, skladovaním a pod. Rozhodujúcim prvkom pre určenie charakteru procesu je potom vznik pridanej hodnoty na výstupe procesu. Ak hovoríme o procesoch v poštovom podniku, kde základnou činnost'ou je premiestňovacia činnost', potom v tomto kontexte je možné chápat' technologické procesy ako procesy súvisiace práve s dopravou, manipuláciou, a pod. Netechnologické poštové procesy sú rovnako chápané ako podporné a môžeme tu zaradit' procesy súvisiace so zabezpečením personálnej problematiky, finančného riadenia, správy IKT a pod.

\footnotetext{
* Ing. Lucia Madleňáková, PhD., Katedra spojov, Fakulta prevádzky a ekonomiky dopravy a spojov, Žilinská univerzita v Žiline, e-mail: Lucia.Madlenakova@fpedas.uniza.sk
} 
Charakteristika procesov v pošte vychádza zo zjednodušenej všeobecnej schémy vstup - proces - výstup. Je nevyhnutné vymedzit' základné prvky procesu, s ktorými je potom možné pri modelovaní pracovat'.

Poštový proces [1] je sústava činností, aktivít alebo úloh, ktorá transformuje vstupy do výstupov za pomoci využitia zdrojov a je vymedzená vnútornými a vonkajšími hranicami.

Vstup môžeme chápat' ako hmotný poštový substrát/element podaný k distribúcií, sprievodný doklad alebo informácie, ktoré sú v poštovom procese transformované na výstupy. Vstupy sa pritom vyznačujú určitou mierou rozptylu a podl'a typu môžeme hovorit' o tzv. konštantných tzn. riadených vstupoch (zásielka, sprievodný doklad, ...), experimentálnych vstupoch ( $\mathrm{v}$ procese testovacej prevádzky nových technologických postupov), ale tiež neriadených vstupoch (náhodne zatriedené zásielky - nesprávne).

Výstup je výsledkom transformácie vstupov, ktorý je vytvorený práve za účelom uspokojenia požiadavky zákazníka procesu. Výstup je definovaný aj ako produkt procesu, za ktorý sa v poštovej praxi považuje dodanie zásielky podl'a stanovených podmienok. Riadenie výstupov procesu umožňuje uplatnenie rôznych ukazovatel'ov výkonnosti procesu pre posúdenie napr. z hl'adiska kvality, efektívnosti či spokojnosti a pod.

Hranice poštového procesu [1] sú stanovené ako požiadavky určujúce, regulujúce alebo inak ovplyvňujúce poštový proces.

Zdroje sú faktory zúčastnené na procese, zabezpečujúce transformáciu vstupov na výstupy. Ide predovšetkým o l'udské a fyzické zdroje, finančné zdroje, postupy a metódy.

Účastníci [7] [9]poštového procesu sú rozdelení podl'a ich špecifického postavenia, vzt’ahu k procesu ale aj podl'a stupňa zodpovednosti: zákazník procesu, dodávatel' procesu, prevádzkovatel' procesu, manažér procesu, operátor procesu.

Medzi d’alšie významné charakteristiky procesu patrí čas, náklady a kvalita. Čas je chápaný ako celkový čas od spustenia procesu až k odovzdaniu výstupov zákazníkovi.

Celkové náklady predstavujú súčet jednotlivých nákladov súvisiacich so všetkými činnost’ami v procese. Kvalita je daná normatívnymi požiadavkami a jej úroveň je závislá nie len na výstupe procesu, ale aj na priebehu celého procesu.

Z vyššie uvedeného potom vyplýva, že základné vlastnosti poštových procesov je možné zhrnút' nasledovne:

- definovanie vstupných a výstupných veličín,

- existencia zret’azenia radu predchádzajúcich a nasledujúcich činností,

- závislost' na ovplyvnitel'ných a neovplyvnitel'ných faktoroch,

- stochastický charakter procesov

- možnost' ovládania priebehu poštového procesu.

\section{Základné princípy modelovania procesov}

Modelovanie je považované za výskumnú techniku/metódu, podstatou ktorej je náhrada skúmaného systému (originálu) modelujúcim systémom (modelom), za účelom získat' pomocou pokusov (experimentov) s modelom informácie o origináli. [6] Metodické postupy a vlastnosti nástrojov a techník modelovania vychádzajú z myšlienky zostrojenia formalizovaného obrazu skúmaného javu alebo systému. Model je teda analógiou medzi dvoma systémami modelovaným aj modelujúcim a vykazuje niektoré vlastnosti zhodné s originálom. Ide najmä o tie, ktoré sú podstatné z hl'adiska ciel'a, ktorý je modelovaním sledovaný, ale tiež štruktúry, času priebehu procesov a pod. Princíp modelovania je úzko spojený s abstrakciou.

Hlavným dôvodom využívania abstrakcie v metódach modelovania je snaha o rozdelenie skúmanej problematiky do menších zvládnutel'ných častí. K jednotlivým prvkom procesu sú často viazané viaceré toky informácií, ktoré súvisia s prebiehajúcimi procesmi a ich vzájomnými vzt’ahmi. Preto je v niektorých prípadoch nevyhnutné pristúpit' 
k zhlukovaniu procesov a objektov a to či už podl'a všeobecných logických súvislostí, alebo podl'a typov činnosti, udalosti, ktoré sa v ich priebehu vyskytujú.

Hierarchické abstrakcie sú prostriedkom rozkladu prvkov skúmaného systému či procesu do detailnej úrovne a platí, že prvky vyššej úrovne pozostávajú z prvkov nižšej úrovne, pričom na každej úrovni je možné charakterizovat' jednotlivé jej prvky a väzby medzi nimi. Pri hierarchickom rozklade je nutné ujasnit' si, aký vzt’ah existuje medzi prvkami. Ako naznačuje obrázok 1, môžeme hovorit' o dvoch typoch hierarchickej abstrakcie: [7]

- celok - čast’ / proces - subproces - ide o agregáciu, čiže primárnu abstrakciu v procesnom modeli, kde sa jednotlivé procesy skladajú z činností, ktoré sú čast'ami procesu. Z opačného uhla pohl'adu, ide teda o zhlukovanie, agregovanie elementárnych častí do procesov (procesných ret’azcov),

- všeobecné - špecifické - ide o generalizáciu vzt’ahu medzi prvkami, kedy hierarchicky nižší prvok je špecifickým variantom prvku vyššieho. Ide o abstrakciu, ktorá je skôr využívaná ako primárna v objektovom modeli, kde je možné uvažovat's jednotlivými špecifickými variantmi nadriadeného pojmu ako je entita a objekt. Nadriadený celok nie je definovaný ako súhrn podriadených častí, ale ako nositel ich spoločných vlastností.

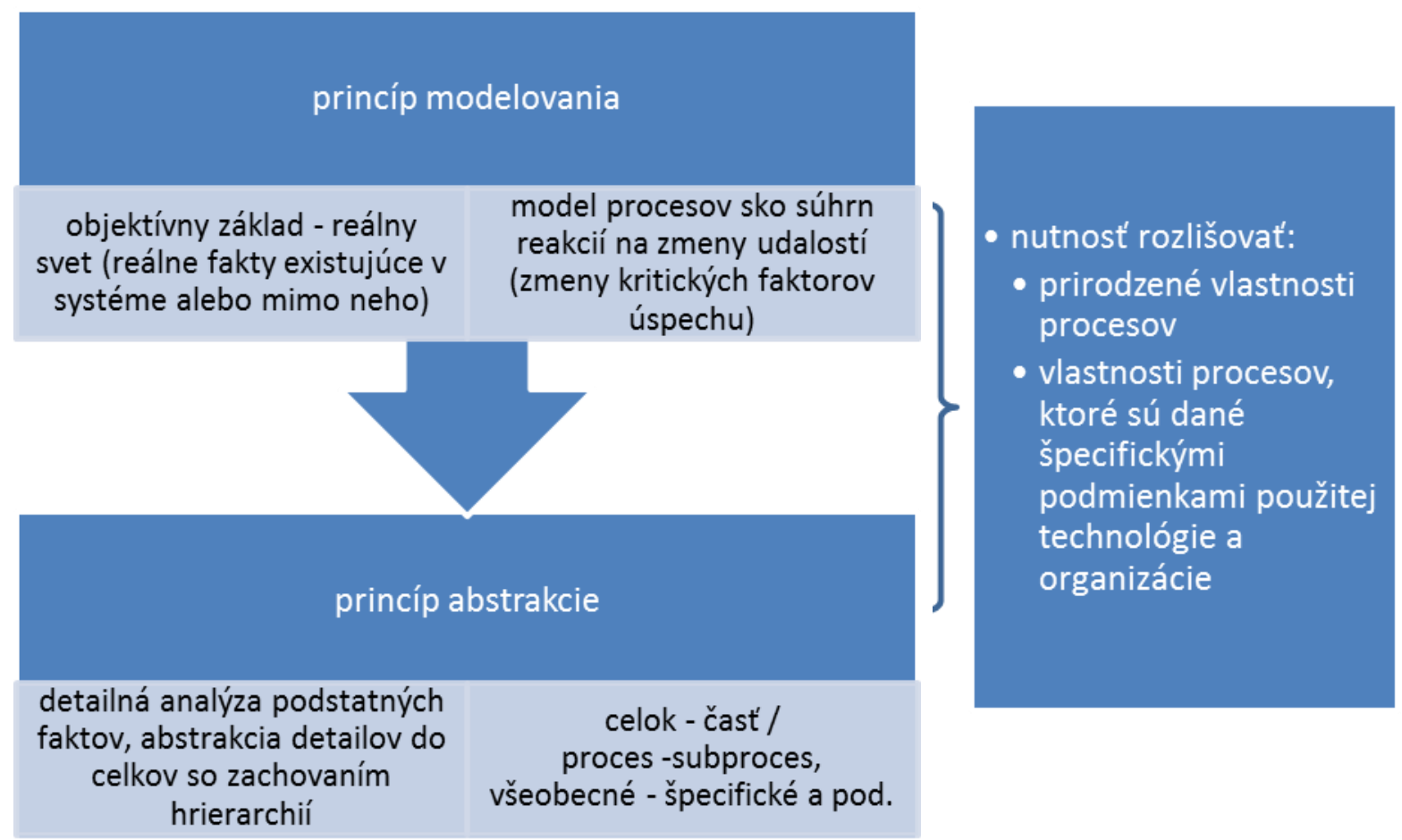

Obrázok 1 Základné princípy modelovania (Zdroj: vlastné spracovanie)

\section{Modelovanie poštových procesov}

Využitie abstrakcie je nevyhnutnou súčast'ou modelovania poštových procesov. Poskytovanie poštových služieb je realizované prostredníctvom funkčného technologického poštového systému. Z globálneho hl'adiska existuje niekol'ko poštových technologických systémov, ktoré sú vzájomne prepojené (existencia niekol'kých poštových operátorov a ich vzájomná spolupráca), prípadne jeden systém môže byt' súčast'ou iného systému. $Z$ tohto pohl'adu je možné danú situáciu znázornit' nasledovne: 


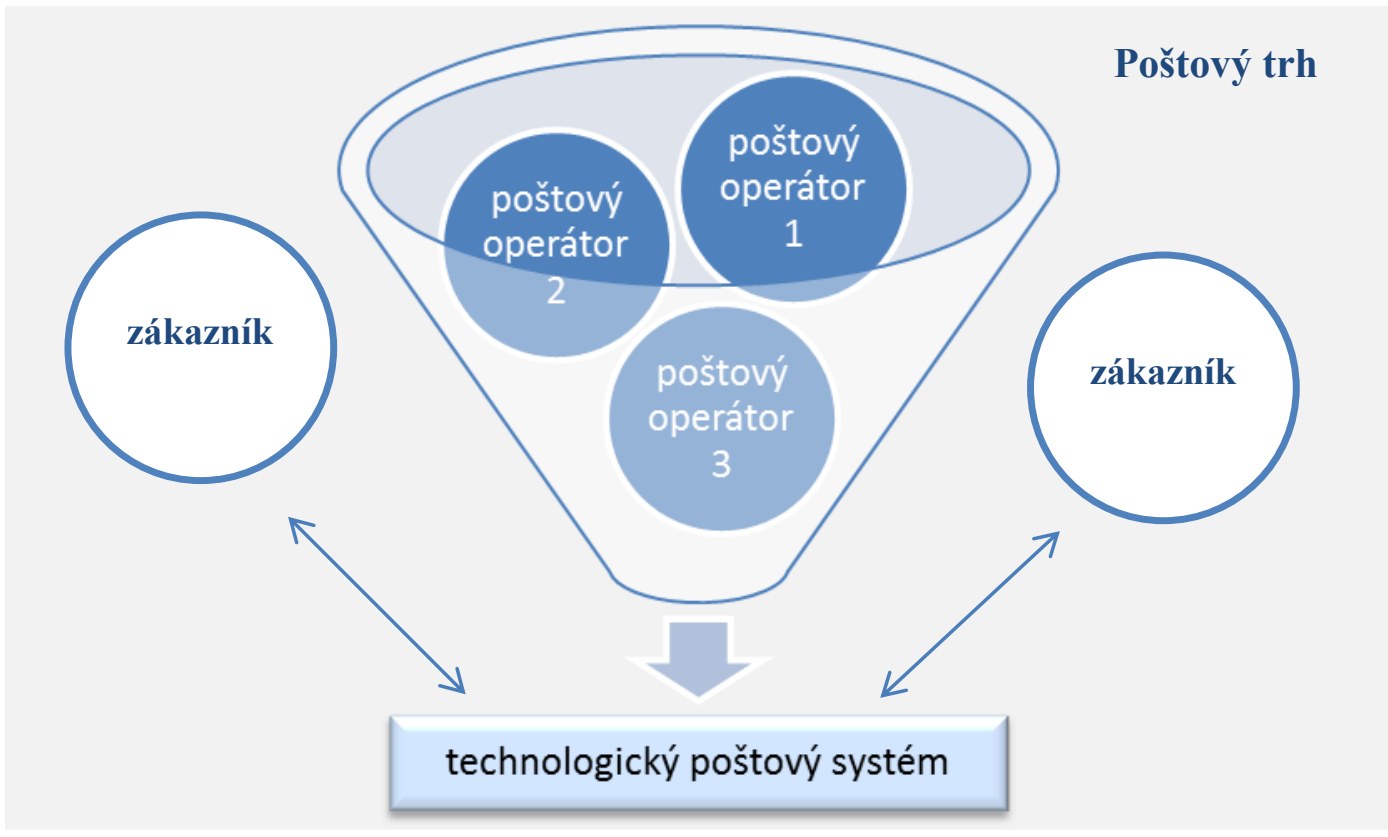

Obrázok 2 Abstrakcia v modelovaní technologických poštových systémov (Zdroj: vlastné spracovanie)

Z existujúceho modelu abstrakciou 1. stupňa získame model zjednodušenej formy infraštruktúry $\mathrm{v}$ technologickom poštovom systéme. Konštrukcia poštovej prepravnej siete jednotlivých poštových operátorov je rôzna, závisí od mnohých faktorov, v zásade sa siete líšia počtom úrovní, počtom a funkcionalitou uzlov (depo, sub-hub, hub, ...).

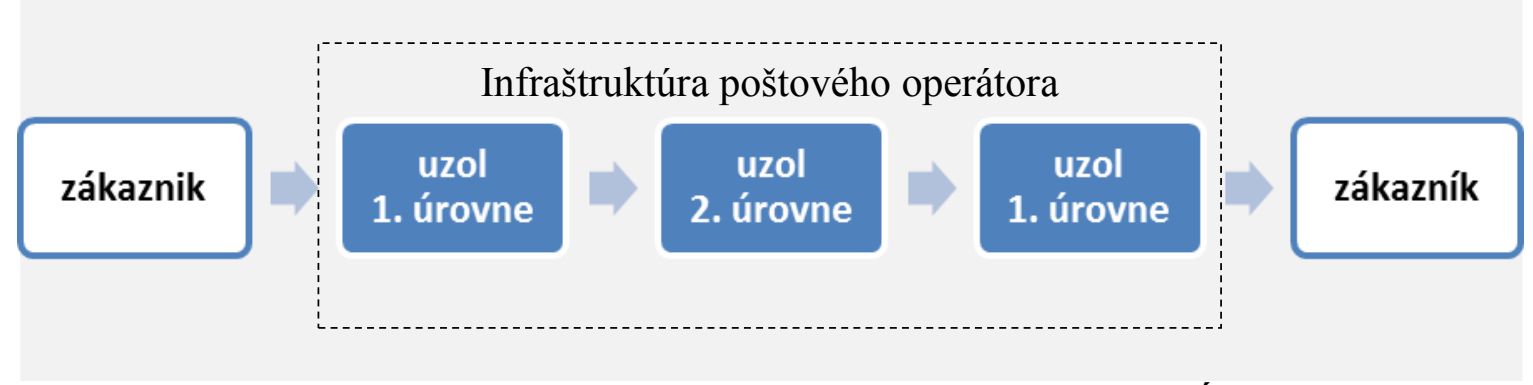

Obrázok 3 Abstrakcia modelovanej situácie 1. úrovne na 2. Úroveň (Zdroj: vlastné spracovanie)

V ukážke využitia abstrakcie pri modelovaní poštových procesov je použitá všeobecná modelová situácia, ktorá nezahŕňa poštový systém ani infraštruktúru konkrétneho poštového operátora. Pri d'alšej úrovni abstrakcie je možné rovnako ostat' vo všeobecnej rovine a riešit' model poskytovanej služby. V závislosti od požiadaviek a potrieb zákazníka bude ciel’om poštového systému zabezpečit' dodanie určitého typu zásielky.

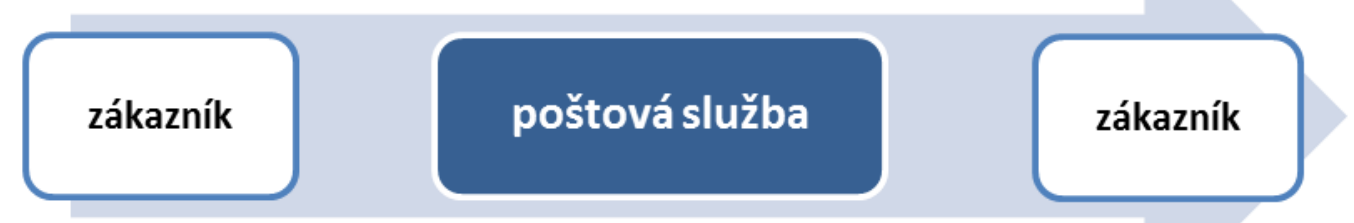

Obrázok 4 Abstrakcia modelovanej situácie 2. úrovne na 3. úroveň (Zdroj: vlastné spracovanie) 


\section{zásielka}

zapísaná neprednostná

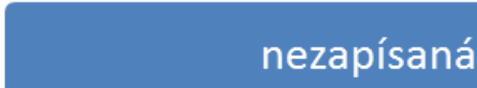

prednostná neprednostná

Obrázok 5 Abstrakcia modelovanej situácie 3. úrovne na 4. úroveň (Zdroj: vlastné spracovanie)

Ak sa vrátime k základnej charakteristike a členeniu procesov, potom aj tvorba modelov poštových procesov vychádza z rozdelenia na kl’účové technologické procesy a podporné - priebežné netechnologické procesy. Významnú úlohu zohráva tvorba procesných tokov, čiže rozčlenenie základného procesu na čiastkové procesy - subprocesy. Ak sa obmedzíme na modelovanie technologických procesov pre premiestňovaciu činnost' poštového podniku, tak model procesných tokov poštovej služby bude vychádzat' zo základnej schémy naznačujúcej činnosti vyplývajúce z definície poštovej služby. [5]

V prvom kroku je nevyhnutné identifikovat' existenciu nutných základných činností a ich usporiadanie $\mathrm{v}$ kontexte klúčových procesov. Ide o zistenie stavu, ako dané činnosti prebiehajú, ako sú popísané a aká je nadväznost' na d’alšie úkony. V tejto fáze dochádza tiež k identifikovaniu podporných procesov a ich kauzálnych vzt’ahov ku procesom kl’účovým.

Druhým krokom, ktorý však čiastočne musí íst' súbežne s prvým krokom je potrebné vytypovat' kl'účové procesy, výsledkom ktorých je vznik pridanej hodnoty smerom k okoliu, čiže zákazníkovi, ktorým v našom prípade bude napr. používatel' poštovej služby. Kl'účové procesy sú $\mathrm{v}$ podstate $\mathrm{v}$ súlade $\mathrm{s}$ primárnou funkciou podniku, čiže jeho kl'účovým produktom, $\mathrm{v}$ našom prípade poštovou službou.
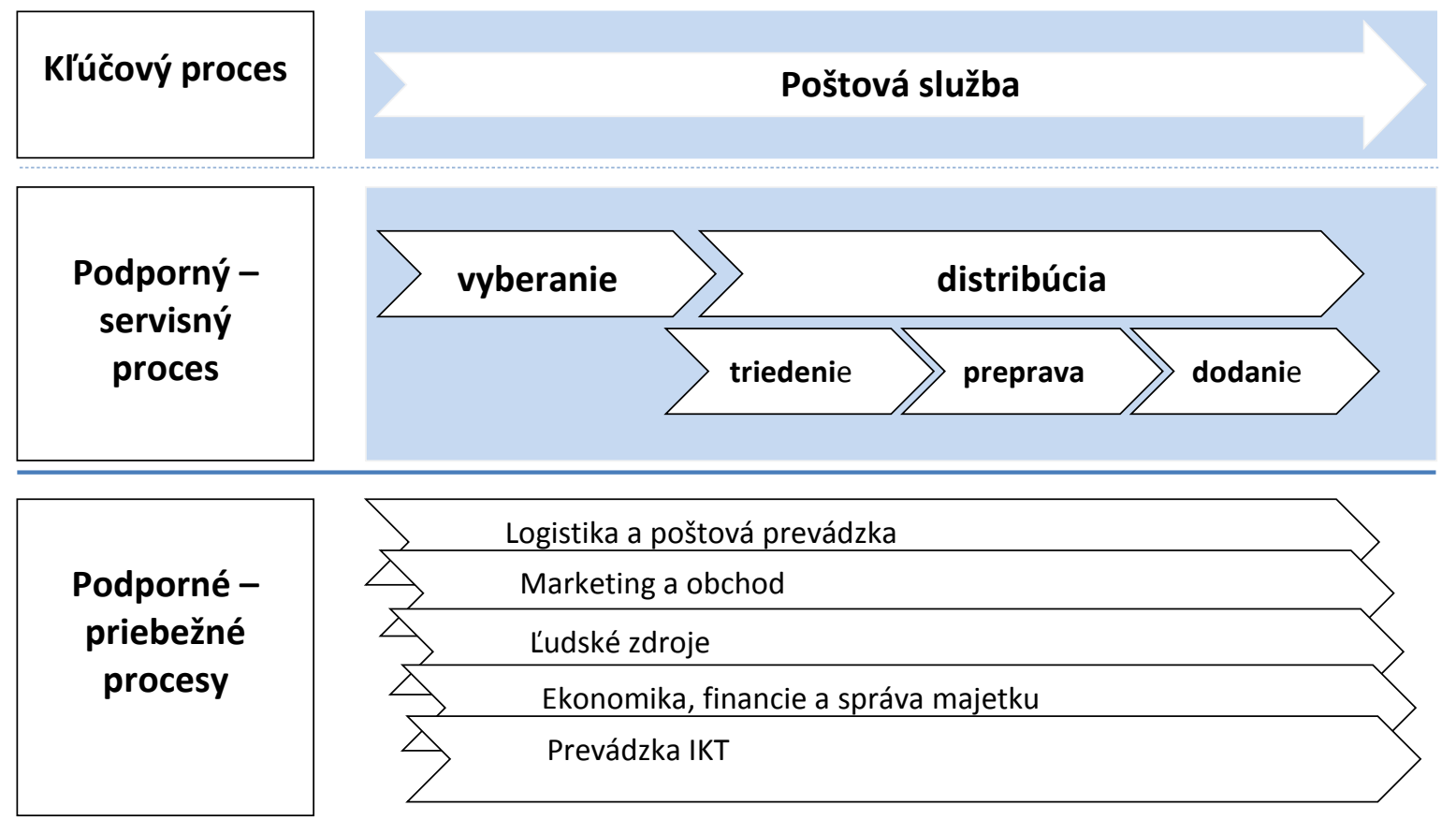

Obrázok 6 Globálny model procesu poštová služba

(Zdroj: vlastné spracovanie) 
Globálny poštový proces môže potom nadobudnút' všeobecné kontúry zobrazené na obrázku 6. Ako je zrejmé, v prvej verzii procesného modelu obsahuje kl'účový proces niekol'ko podporných - servisných procesov, ktoré sa pri d’alšom skúmaní stanú predmetom dekompozície a budú riešené ako kl'účové oblasti. V rovine priebežných podporných procesov, teda tých, ktoré boli vyššie určené ako netechnologické, boli intuitívne vytypované procesné oblasti, z ktorých každá nesporne zahŕňa niekol'ko procesov. Tieto už nebudú d'alej procesne analyzované a popisované.

Tabul'ka Chyba! Dokument neobsahuje žiadny text so zadaným štýlom..1Popisná tabul'ka globálneho procesu „Poštová služba“"

\begin{tabular}{|c|c|}
\hline & Identifikácia \\
\hline $\begin{array}{l}\text { Názov procesu (vyjadrenie zmyslu, } \\
\text { určenia a obsahu) }\end{array}$ & Poštová služba \\
\hline $\begin{array}{l}\text { Strategický ciel' (ciele a primárne } \\
\text { funkcie, ktoré proces podporuje) }\end{array}$ & $\begin{array}{l}\text { Uspokojenie potrieb zákazníka } \\
\text { Napĺňanie stratégie rozvoja podniku } \\
\text { Zabezpečenie základnej obslužnosti územia } \\
\text { Maximalizácia efektívnosti výkonu podniku } \\
\text { Kvalitatívne plnenie }\end{array}$ \\
\hline $\begin{array}{l}\text { Produkt/služba procesu (základný } \\
\text { výstup procesu) }\end{array}$ & Dodanie zásielky \\
\hline $\begin{array}{l}\text { Špecifikácia procesu (stručný popis } \\
\text { zmyslu a obsahu procesu) }\end{array}$ & $\begin{array}{l}\text { Sústava činností a aktivít, súvisiacich s vyberaním } \\
\text { a distribúciou za účelom dodania zásielky }\end{array}$ \\
\hline $\begin{array}{l}\text { Vlastník procesu (charakteristika, } \\
\text { identifikácia, meno vlastníka) }\end{array}$ & Operačný manažér/manažér poštovej prevádzky a logistiky \\
\hline $\begin{array}{l}\text { Zákazníci procesu (konkrétne, } \\
\text { abstraktné role zákazníka) }\end{array}$ & $\begin{array}{l}\text { Používatel' poštovej služby: odosielatel', adresát } \\
\text { Rola: FO, PO, vláda, NRA }\end{array}$ \\
\hline $\begin{array}{l}\text { Oblast' zlepšenia/problémy } \\
\text { (vymedzenie oblastí nutného } \\
\text { zlepšenia alebo zmien procesu) } \\
\end{array}$ & $\begin{array}{l}\text { Optimalizácia poštovej siete } \\
\text { Obnova vozového parku }\end{array}$ \\
\hline Metriky (meradlá výkonu procesu) & $\begin{array}{l}\text { Počet prístupových miest/km² } \\
\text { Počet obyvatel'ov/1 prístupové miesto } \\
\text { Počet podaných zásielok/obyvatel'a } \\
\text { Počet dodaných zásielok/obyvatel'a } \\
\text { Počet zásielok na zamestnanca } \\
\text { \% prevádzok vybavených IT } \\
\text { Pomocné ukazovatele: kvalitatívne } \\
\text { - lehota prepravy } \\
\text { - } \quad \text { spokojnost' zákazníkov } \\
\text { - dostupnost' }\end{array}$ \\
\hline $\begin{array}{l}\text { Štartovacia udalost' (primárny } \\
\text { podnet, ktorý vedie ku spusteniu } \\
\text { celého procesu) }\end{array}$ & Podanie zásielky \\
\hline $\begin{array}{l}\text { Podmienky (všeobecné podmienky } \\
\text { spustenia/priebehu/ukončenia } \\
\text { procesu) }\end{array}$ & $\begin{array}{l}\text { Všeobecné povolenie na poskytovanie poštových služieb } \\
\text { Poštová licencia }\end{array}$ \\
\hline $\begin{array}{l}\text { Informačné systémy (zoznam IS, } \\
\text { ktoré podporujú proces) }\end{array}$ & APO, Logis, SAP, ... \\
\hline $\begin{array}{l}\text { Dokumenty (riadiace dokumenty } \\
\text { organizácie a d'alšie predpisy týkajúce } \\
\text { sa procesu) }\end{array}$ & $\begin{array}{l}\text { Zákon o poštových službách } \\
\text { Poštové a obchodné podmienky poskytovatel'a } \\
\text { Tarifa } \\
\text { Prevádzkové predpisy } \\
\text { Smernice EK }\end{array}$ \\
\hline
\end{tabular}




\section{Zdroj: Vlastné spracovanie}

Takto zostavený model môžeme považovat' za statický štrukturálny pohl'ad na procesy a je vhodné doplnit' ho popisnou tabul'kou, ktorá obsahuje štandardné atribúty ako ciel', procesný produkt, zákazník procese, špecifikácia procesu a pod. Tabul'ka by mala byt' vyjadrením základných charakteristík procesu, nie však popisom jeho činností. V prípade, popisovania generického procesu, ktorý zahŕn̆a rôzne varianty vzájomne sa líšiace práve jednotlivými atribútmi, ktoré spájajú spoločné procesné súvislosti, ciele, vlastníka procesu a pod., je možné, že v priebehu d'alších podrobnejších analýz dôjde $\mathrm{k}$ ich rozdeleniu na kl'účové procesy podl'a jednotlivých variantov. [5]

Na rozdiel od globálneho modelu, ktorý zahŕňa celý systém procesov, model priebehu procesov resp. toku procesov popisuje dynamickú stránku jedného procesu. Jeho zmyslom je zaznamenat' logický postup jednotlivých činností, ako po stránke obsahovej, tak i časovej. Práve časové hl'adisko je charakteristické pre detailné spracovanie procesov. Pri globálnych modeloch sa do úvahy neberie logická následnost' činností, model je v podstate vyjadrením vecných súvislostí resp. typových vzt’ahov medzi procesmi.

Pri modelovaní technologického procesu „poštová služba“ je potrebné uvedomit' si, že budeme riešit' zabezpečenie premiestňovacieho procesu zásielky. Základný proces je potrebné d'alej dekomponovat' na čiastkové procesy v závislosti od typu činnosti, miesta výkonu a času. [5]

Pri zobrazovaní procesného toku súvisiaceho s realizáciou poštovej služby je potrebné si uvedomit', že jej zabezpečenie môže súvisiet' s premiestňovaním zásielok rôznych kategórií, ktorých charakteristické vlastnosti si vyžadujú aj realizáciu špecifických úkonov, či už na vstupe alebo výstupe procesu, alebo aj počas jeho priebehu. Ide o špecifiká súvisiace najmä s kvalitatívnymi požiadavkami, ako je rýchlost' prepravy (zásielky expresnej poštovej služby, zásielky 1. triedy, 2. triedy) alebo aj miera zodpovednosti vlastníka procesu za zásielku (zapísané zásielky - poistené, doporučené a nezapísané zásielky). S týmito atribútmi je úzko spojená aj použitá technológia a samozrejme aj typ siete, ktorou bude zásielka prechádzat'.

Použitím už spomínanej abstrakcie, môžeme z globálneho poštového procesu, ktorý je vo svojich základných rysoch rovnaký pre akéhokolvvek poštového operátora vyňat' proces poštová služba. Poštovú službu je možné vnímat' ako požiadavku zákazníka na zabezpečenie dodania zásielky. V tejto úrovni je potrebné uvažovat' o poštovom systéme, v ktorom bude služba poskytnutá, to znamená, že použité technológie, technologické postupy a typ infraštruktúry môžu byt' u jednotlivých operátorov rôzne. Principiálne môžeme hovorit' o dvoch skupinách operátorov a to poskytovatel'ovi univerzálnej služby a ostatných poštových podnikoch - alternatívnych operátoroch.

Modelovanie procesov tak môžeme rozdelit' na dva varianty riešenia vhodné pre modelovanie poštových procesov v podmienkach vybraného operátora.

\section{poštová služba}

poskytovatel' univerzálnej služby

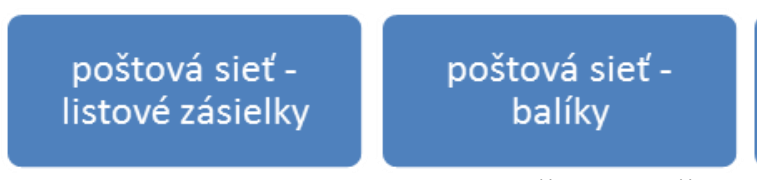

Obrázok 7 Dekompozícia poštovej služby v poštovom systéme (Zdroj: vlastné spracovanie) alternatívni poskytovatelia

poštová siet' expresné služby poštová siet' všetky zásielky 
Vhodným nástrojom pre modelovanie poštových procesov sa javí konštruovanie procesných máp s využitím hierarchického štruktúrovania. Procesné mapy umožňujú zobrazovanie procesov vo forme diagramov tak, aby zostrojený grafický obraz poskytol všetky potrebné informácie aj pre d’alšiu analýzu. Proces, bude zostrojený na základe agregácie jednotlivých, vzájomne nadväzujúcich činností, ktoré sú však podmienené vznikom nejakého impulzu či podnetu, ktorý môže vzniknút' bud' z vonkajšieho prostredia, za takýchto podmienok hovoríme o udalosti a ide $\mathrm{v}$ podstate o podnet objektívny, alebo je dôsledkom vnútornej situácie, v ktorej sa daná činnost' práve nachádza a voči procesu je táto situácia subjektívna a hovoríme jej stav procesu. Nevyhnutnou súčast'ou modelovania procesu je znázornenie väzieb a nadväznosti medzi jednotlivými činnost’ami, ktoré znázorňujú usporiadanie priebežných aktivít čím je definovaná celková štruktúra procesu. [3]

Správne znázornený procesný model potom okrem vyššie uvedených prvkov znázorňuje aj nadväznost' jednotlivých subprocesov ich paralelný alebo sekvenčný priebeh, a tiež zobrazuje vzt’ahy medzi jednotlivými funkčnými celkami, funkciami, dokumentmi a pod. [2]

Modelovanie poštových procesov s možnost’ou ich vizualizácie je významnou aktivitou z hl'adiska zabezpečenia:

- jednoznačnosti, prehl'adnosti, zrozumitel'nosti a dobrej komunikácie, čo následne umožňuje lepšie pochopenie súčasného stavu,

- zvýraznenia vzt'ahov medzi tzv. vnútornými a vonkajšími zákazníkmi pošty,

- identifikácie všetkých vstupov a výstupov s možnost'ou ich členenia podl'a jednotlivých typov a kategórií,

- vymedzenia hranice procesu (miesta, kde proces prijíma zdroje, vydáva výstupy, dochádza $\mathrm{k}$ zmene riadenia a pod.) a zaznamenania miest a okamihov, kedy $\mathrm{v}$ procese dochádza $\mathrm{k}$ vetveniu, kde vznikajú slučky, väzby medzi procesmi a pod.,

- poskytovania rýchlej signalizácie a odhalenia výrazných problémov procesu a identifikácie príležitostí pre lokálne zlepšovanie a optimalizáciu procesov,

- vytvorenia modelu formou diagramu, či procesnej mapy, čo umožňuje vznik výstižného a stručného vizuálneho materiálu, ktorý pomáha aplikovaniu systémov kvality, či hodnotenia výkonnosti podl'a vybraných metód a prístupov.

\section{Závery a diskusia}

Modelovanie poštových procesov je z pohl'adu úspešnosti podniku rovnako významné ako modelovanie akéhokol'vek vnútropodnikového procesu. Uplatnením vhodných nástrojov modelovania, simulácie či optimalizácie u známych a opakovaných procesov, ale i u procesov novo vniknutých je dôležitým predpokladom pre overenie slabých miest v celom ret'azci premiestňovacieho procesu. Náhodný charakter výskytu poštovej služby udáva d’alší dôvod na podrobné monitorovanie procesov aj z hl'adiska zabezpečenia optimálneho pokrytia dopytu či kapacitných požiadaviek (l'udské zdroje, technické prostriedky, ...) spracovatel'ských centier na pri realizácií poštovej služby na siet’ovej úrovni poštového systému.

\section{Literatúra}

[1] ČOREJOVÁ, T., ROSTÁŠOVÁ, M.: Diagnostický postup v manažérstve kvality v pošte, ŽU 1999, ISBN 80-7100-619-X

[2] ČUNDERLÍK, M., VACULÍK,J. KOLAROVSZKI, P.: Multimedial presentation about postal technology processes - Automatic assorting line Siemens In: Telekom 2007 
[elektronický zdroj] : nacionalna konferencija s meždunarodno učastije : 11.-12.10.2007 Varna : dokladi. - S.l.: s.n., 2007. - ISBN 978-954-8329-93-4. - Požiadavky na systém: CD-ROM mechanika.

[3] KOVÁČIKOVÁ, M: Procesné riadenie v organizáciách .In: Diagnostika podniku, controlling a logistika [elektronický zdroj] : VI. medzinárodná vedecká konferencia : zborník prednáśok a príspevkov : 12.-13. apríl 2012, Žilina. - Žilina: Žilinská univerzita, 2012. - ISBN 978-80-554-0502-5. - CD-ROM, s. 223-228.

[4] MADLEŇÁKOVÁ, L Procesné riadenie kvality v poštových službách. In: IPoCC International Postal and e-Communications Conference: sborník př́spěvků mezinárodní konference IPoCC "Možnosti rozvoje poštovních služeb a elektronických komunikací" = proceedings of the IPoCC Conference "Possibilities of Postal Services and eCommunications Development" : Pardubice, September 13th-14th, 2012. - [Pardubice]: Institut Jana Pernera, 2012. - ISBN 978-80-86530-84-0. - s. 144-149.

[5] MADLEŇÁKOVÁ, L Vrstvový model poštového systému. Habilitačná práca. Žilinská univerzita v Žiline. Fakulta prevádzky a ekonomiky dopravy a spojov. Žilina: FPEDAS, ŽU, 2013. 108 s.

[6] PASTOR, O., TUZAR, A.: Teorie dopravních systémů, ASPI Praha, 2007, ISBN 978-807357-285-3

[7] ŘEPA, V.: Procesně řízená organizace. Vydavatel'stvo: Grada, 2012, ISBN: 9788024741284

[8] SALAVA, D. - ŠVADLENKA, L. Modeling of Transport Demand in Relation to Competition on Transport Market. Perner's Contacts, 2011, vol. 6, no. 3, s. 135-139. ISSN: 1801-674X.

[9] SVOZILOVÁ, A.: Zlepšování podnikových procesů. Vydavatel'stvo GRADA Publishing,a.s., Praha 2011, ISBN 978-80-247-3938-0

\section{Grantová podpora}

VEGA 1/0421/12 Modelovanie difúzie znalostí v podnikových hodnotových ret’azcoch 